\title{
Evaluasi Ketepatan Dosis dan Obat Antihipertensi Terhadap Pada Pasien Hipertensi Rawat Jalan Di Rumah Sakit Bhakti Wira Tamtama Semarang
}

\section{Evaluation Of The Dose and Antihypertensive Drugs In Outpatient Hypertension at Bhakti Wira Tamtama Hospital Semarang}

\author{
Wycidalesma $^{(1)}$, Richa Yuswantina ${ }^{(2)}$ \\ (1)(2)Program Studi Farmasi, Universitas Ngudi waluyo \\ Email: wycidalesma@gmail.com
}

\begin{abstract}
ABSTRAK
Hipertensi adalah peningkatan tekanan darah sistolik $>140 \mathrm{mmHg}$ dan tekanan darah diastolik $>90 \mathrm{mmHg}$ dan merupakan faktor terbesar penyebab mobiditas dan mortalisis. Ketidaktepatan terapi hipertensi dapat menyebabkan terjadinya komplikasi yang dapat memperburuk keadaan penderita.Penelitian ini bertujuan untuk mengetahui ketepatan penggunaan obat dan dosis obat antihipertensi. Penelitian ini merupakan jenis penelitian deskriptif non eksperimental menggunakan pendekatan retrospektif. Jumlah sampel 90 yang memenuhi kriteria inklusi dan eksklusi diambil secara purposive sampling. Analisis data menggunakan program SPSS (Statistic Package for the Social Science) meliputi analisis univariat dan bivariat. Hasil penelitian menunjukkan bahwa ketepatan obat terjadi pada 85 pasien $(94,44 \%)$. Ketepatan dosis obat terjadi pada 90 pasien $(100 \%)$
\end{abstract}

Kata Kunci : Ketepatan, Hipertensi, Obat, Dosis

\begin{abstract}
Hypertension is a increased in systolic blood pressure $>140 \mathrm{mmHg}$ and diastolic blood pressure $>90 \mathrm{mmHg}$ and the biggest factor causing mobidity and mortality. The inaccuracy in hypertension therapy can cause complication and make if worse. The objective of the study is to determine the accuracy and the dose of antihypertensive drugs. This research was non-experimental descriptive research using a retrospective approach. The number of samples 90 who met the inclusion and exclusion criteria taken by purposive sampling. Data analysis used the SPSS program (Statistical Package for the Social Science) included univariate and bivariate analysis. The results show that the accuracy of the drug is in 85 patients $(94,44 \%)$, and the inaccuracy of the drug is in 5 patients $(5,56 \%)$. Whereas the accuracy of drug dosage is in 90 patients $(100 \%)$. The accuracy of antihypertensive drug is 85 patients $(94,44 \%)$, while the accuracy of the dose is 90 patients $(100 \%)$.
\end{abstract}

Keywords: Accuracy, Hypertension, Drug, Dose

\section{PENDAHULUAN}

\section{Latar Belakang}

Hipertensi adalah peningkatan tekanan darah sistolik $>140 \mathrm{mmHg}$ dan tekanan darah diastolik $>90$ $\mathrm{mmHg}$ dan merupakan faktor terbesar penyebab mobiditas dan mortalitas. Ketidaktepatan terapi hipertensi dapat menyebabkan terjadinya komplikasi yang dapat memperburuk keadaan penderita.Terapi hipertensi menurut guideline JNC 8 adalah perubahan target tekanan darah sistolik pada 
pasien berusia 60 tahun ke atas menjadi $<150 / 90 \mathrm{mmHg}$ dan target tekanan darah pada pasien berusia 60 tahun ke bawah berubah menjadi $<140 / 90 \mathrm{mmHg}$. Sedangkan pasien dewasa dengan diabetes atau penyakit ginjal kronik Joint National Commission (JNC VIII), rekomendasi target tekanan darah yang harus dicapai adalah $<140 / 90 \mathrm{mmHg}$ (JNC VIII, 2014).

Prevalensi hipertensi di Indonesia menurut Riskesdas tahun 2013 sekitar $25,8 \%$ dan mengalami peningkatan pada tahun 2018 sekitar $34,1 \%$. Pada umur $\geq 18$ tahun di Indonesia yang didapatkan melalui jawaban pernah di diagnosis tenaga kesehatan sebesar 9,4. Jadi cakupan tenaga kesehatan hanya $36,8 \%$, sebagian besar $63,2 \%$ kasus hipertensi di masyarakat tidak terdiagnosis.

Pemberian obat dikatakan tepat apabila jenis obat yang dipilih berdasarkan pertimbangan manfaat dan risiko. Ketepatan obat dinilai berdasarkan kesesuaian pemilihan obat dengan mempertimbangkan diagnosa yang tertulis dalam rekam medik dan dibandingkan dengan standar yang digunakan pemberian obat antihipertensi tanpa penyakit penyerta dengan menggunakan monoterapi. Sedangkan kriteria tepat dosis adalah tepat dalam frekuensi pemberian, dosis yang diberikan dan jalur pemberian obat kepada pasien. Bila peresepan obat antihipertensi berada pada rentang dosis minimal dan dosis per hari yang dianjurkan maka peresepan dikatakan tepat dosis (Kemenkes RI, 2011).

Evaluasi ketepatan penggunaan obat dan dosis obat antihipertensi bertujuan untuk memastikan penggunaan obat yang rasional kepada penderita hipertensi. Dimana penggunaan obat yang rasional sangat penting untuk meningkatkan keberhasilan terapi (WHO, 2013).

Ketepatan pemilihan obat tersebut bertujuan agar penggunaan obat sebagai tanggung jawab bersama dapat menghasilkan outcome terapi yang optimal (Kusumadewi, 2011). Keberhasilan (outcome) terapi adalah pengobatan hipertensi di rumah sakit salah satunya dapat dilihat dari penurunan tekanan darah pasien mencapai target dan keadaan pasien dari perkembangan tanda - tanda fisik pasien selama pasien menjalani pengobatan di Rumah Sakit Bhakti Wira Tamtama Semarang pada Periode Januari-Maret tahun 2019.

Berdasarkan uraian maka peneliti ingin melakukan penelitian mengenai "Evaluasi Ketepatan Obat dan Dosis Obat Antihipertensi terhadap Keberhasilan Terapi pada Pasien Hipertensi Rawat Jalan di Rumah Sakit Bhakti Wira Tamtama Semarang Periode Januari-Maret 2019.

\section{Tujuan Penelitian}

a. Untuk mengetahui ketepatan penggunaan obat antihipertensi.

b. Untuk mengetahui ketepatan dosis obat antihipertensi.

\section{METODE PENELITIAN}

Penelitian ini merupakan penelitian non eksperimental dengan pendekatan deskriptif. Pengambilan data dilakukan secara retrospektif yang dilakukan di Rumah Sakit Bhakti Wira Tamtama Semarang. Pengambilan data dengan melakukan penelusuran catatan pengobatan pasien pada kartu rekam medik pasien. Kemudian menggunakan analisa data univariat dan analisa data bivariat dengan SPSS menggunakan uji statistik chi-square dengan tingkat kepercayaan $95 \%$ dan tingkat signifikan (a) $<0,05$. Penelitian dilakukan pada 
bulan Juni tahun 2019 dengan jumlah sampel yang masuk kriteria inklusi dan eksklusi sebanyak 90 sampel. Kriteria inklusi adalah kriteria dimana subjek penelitian dapat mewakili dalam sampel penelitian, memenuhi syarat sebagai sampel yaitu, pasien yang didiagnosa hipertensi tanpa penyakit penyerta kardiovaskuler, pasien hipertensi umur
18-60 tahun, pasien hipertensi tetap selama 3 bulan diterapi, pasien hipertensi yang mendapatkan obat dengan terapi yang sama di Rumah Sakit Bhakti Wira Tamtama Semarang. Kriteria Eksklusi adalah data rekam medis dan resep pasien hipertensi rawat jalan pada tahun 2019 yang tidak lengkap dan tidak dapat terbaca jelas, dan pasien ibu hamil.

\section{HASIL DAN PEMBAHASAN}

\section{Karakteristik Pasien}

Tabel 1. Distribusi Frekuensi Karakteristik Pasien Hipertensi Tanpa Penyakit Penyerta Kardiovaskuler yang Menerima Obat Hipertensi Berdasarkan Kelompok Usia dan Jenis Kelamin

\begin{tabular}{cccc}
\hline & & Jumlah & Persentase (\%) \\
\hline \multirow{2}{*}{ Usia (tahun) } & $18-36$ & 0 & 0 \\
\cline { 2 - 4 } & $37-50$ & 43 & 47,8 \\
\cline { 2 - 4 } & $51-60$ & 47 & 52,2 \\
\hline \multirow{2}{*}{ Jenis Kelamin } & Perempuan & 59 & 65,6 \\
\cline { 2 - 4 } & Laki-Laki & 31 & 34,4 \\
\hline Total & & $\mathbf{9 0}$ & $\mathbf{1 0 0}$ \\
\hline
\end{tabular}

Karakteristik pasien hipertensi berdasarkan jenis kelamin bertujuan untuk mengetahui perbandingan jumlah pasien perempuan dan lakilaki yang menderita hipertensi tanpa penyakit penyerta kardiovaskuler. Hasil penelitian pada 90 pasien hipertensi tanpa penyakit penyerta kardiovaskuler paling banyak terjadi pada pasien perempuan sekitar 59 pasien $(65,6 \%)$ dan 31 pasien $(34,4 \%)$ terjadi pada pasien laki-laki. Hal ini kemungkinan dapat terjadi karena adanya pengaruh Sindrom withdrawal esterogen pada wanita yang telah mengalami masa menopause. Hal ini dikarenakan wanita memiliki faktor resiko yang beragam diantaranya obesitas sentral, tingginya kolesterol total, dan rendahnya HDL yang dapat mencetuskan terjadinya hipertensi. Berdasarkan umur yang paling banyak terjadi pada umur (37-50 tahun) sebanyak 43 pasien $(47,8 \%)$, dan kategori umur (51-60) sebanyak 47 pasien $(52,2 \%)$.

\section{Karakteristik Obat}

Tabel 2. Distribusi Penggunaan Obat Antihipertensi Tunggal pada Pasien Hipertensi Tanpa Penyakit Penyerta Kardiovaskuler

\begin{tabular}{|c|c|c|c|c|}
\hline Varian & Golongan Obat & Nama Obat & Jumlah & $\begin{array}{c}\begin{array}{c}\text { Persentase } \\
\mathbf{N}=90(\%)\end{array}\end{array}$ \\
\hline \multirow{4}{*}{ Tunggal } & ARB & Candesartan & 13 & 29,55 \\
\hline & $\mathrm{CCB}$ & Amlodipin & 30 & 68,18 \\
\hline & ACEI & Lisinopril & 1 & 2,27 \\
\hline & & Total & 44 & 100 \\
\hline \multirow{11}{*}{ Kombinasi } & \multirow{3}{*}{$\mathrm{CCB}+\mathrm{ARB}$} & Amlodipin+Candesartan & $\frac{44}{20}$ & 43,48 \\
\hline & & $\begin{array}{c}\text { Diltiazem(Herbeser CD) } \\
+ \text { Candesartan }\end{array}$ & 2 & 4,35 \\
\hline & & Amlodipin+Irbesartan & 5 & 10,87 \\
\hline & $\mathrm{CCB}+\mathrm{ACEI}$ & Amlodipin+Lisinopril & 6 & 13,04 \\
\hline & $\mathrm{ARB}+\mathrm{CCB}$ & Candesartan+Lisinopril & $\frac{1}{1}$ & 2,17 \\
\hline & \multirow{2}{*}{$\mathrm{CCB}+\beta$-Blocker } & Amlodipin+Bisoprolol & $\frac{2}{2}$ & 4,35 \\
\hline & & Amlodipin+Propanolol & $\frac{2}{5}$ & 10,87 \\
\hline & $\mathrm{CCB}+\mathrm{ARB}+\mathrm{CCB}$ & $\begin{array}{l}\text { Amlodipin+Candesartan+ } \\
\text { Diltiazem(Herbeser CD) }\end{array}$ & 2 & 4,35 \\
\hline & $\mathrm{CCB}+\mathrm{ARB}+\beta$-Blocker & $\begin{array}{c}\text { Amlodipin+Candesartan } \\
+ \text { +Bisoprolol }\end{array}$ & 2 & 4,35 \\
\hline & \multirow[t]{2}{*}{ ARB+Diuretik+CCB } & $\begin{array}{c}\text { Candesartan+HCT }+ \\
\text { Diltiazem }(\text { Herbeser CD) }\end{array}$ & 1 & 2,17 \\
\hline & & Total & 46 & 100 \\
\hline
\end{tabular}




\author{
Keterangan : \\ Diuretik : \\ ARB : Angiotensin II Reseptor Blocker \\ CCB : Calcium Channel Blocker \\ ACEI : Angiotensin Converting Enzym Inhibitor \\ $\beta$-Blocker : Penyekat $\beta$-Adreno Reseptor
}

Berdasarkan tabel 2, penggunaan obat antihipertensi tunggal yang banyak digunakan adalah obat golongan CCB (Calcium Channel Blocker) yaitu Amlodipin sebanyak 30 pasien dengan persentase sebanyak $68,18 \%$. Dan pengobatan hipertensi kombinasi obat yang banyak diresepkan adalah antara CCB dengan ARB (Amlodipin dengan Candesartan) yaitu sebanyak $22,2 \%$. Pengobatan hipertensi berbeda-beda antara satu pasien dengan pasien lain, pengobatan tersebut bersifat individual dengan memperhatikan bahwa efek obat terkadang tidak sama bagi setiap individu (Kowalski, 2010).

3. Evaluasi Ketepatan Obat Antihipertensi

Tabel 3. Distribusi Frekuensi Tepat Obat Antihipertensi pada Pasien Hipertensi Tanpa Penyakit Penyerta Kardiovaskuler Berdasarkan Joint National Committee VII dan American Heart Associantion (AHA) 2017.

\begin{tabular}{|c|c|c|c|c|c|c|}
\hline \multirow{2}{*}{ Varian } & \multirow{2}{*}{ Golongan } & \multirow{2}{*}{ Obat Antihipertensi } & \multicolumn{2}{|c|}{$\begin{array}{c}\text { Evaluasi Tepat } \\
\text { Obat }\end{array}$} & \multirow[t]{2}{*}{ Jumlah } & \multirow[t]{2}{*}{$\begin{array}{c}\text { Persentase } \\
(\%)\end{array}$} \\
\hline & & & Tepat & $\begin{array}{l}\text { Tidak } \\
\text { tepat }\end{array}$ & & \\
\hline \multirow{3}{*}{ Tunggal } & ARB & Candesartan & $\checkmark$ & & 13 & 29,55 \\
\hline & $\mathrm{CCB}$ & Amlodipin & $\checkmark$ & & 30 & 68,18 \\
\hline & ACEI & Lisinopril & $\checkmark$ & & 1 & 2,27 \\
\hline \multirow{10}{*}{ Kombinasi } & Total & & 44 & & 44 & 100 \\
\hline & $\mathrm{CCB}+\mathrm{ACEI}$ & Amlodipin+Lisinopril & $\checkmark$ & & 6 & 13,04 \\
\hline & ARB+ACEI & Candesartan + Lisinopril & 2 & & 1 & 2,17 \\
\hline & \multirow{3}{*}{$\mathrm{CCB}+\beta$-Blocker } & Amlodipin+Bisoprolol & $\checkmark$ & & 1 & 2,17 \\
\hline & & Amlodipin+Bisoprolol & & 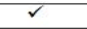 & 1 & 2,17 \\
\hline & & Amlodipin+Propanolol & $\checkmark$ & & 5 & 10,87 \\
\hline & $\mathrm{CCB}+\mathrm{ARB}+\mathrm{CCB}$ & $\begin{array}{c}\text { Amlodipin+Candesartan } \\
+ \text { +Herbeser CD }\end{array}$ & & $\checkmark$ & 2 & 4,35 \\
\hline & $\mathrm{ARB}+$ Diuretik $+\mathrm{CCB}$ & $\begin{array}{c}\text { Candesartan }+\mathrm{HCT} \\
\text { +Herbeser } \mathrm{CD}\end{array}$ & $\checkmark$ & & 1 & 2,17 \\
\hline & $\begin{array}{c}\mathrm{CCB}+\mathrm{ARB}+\beta- \\
\text { Blocker }\end{array}$ & $\begin{array}{c}\text { Amlodipin+Candesartan } \\
+ \text { Concor }\end{array}$ & & $\checkmark$ & 2 & 4,35 \\
\hline & Total & & 41 & 5 & 46 & 100 \\
\hline
\end{tabular}

Keterangan :

ARB : Angiotensin II Reseptor Blocker

CCB : Calcium Channel Blocker

ACEI : Angiotensin Converting Enzyme Inhibitor

Berdasarkan tabel 3, obat diagnosa yang telah ditegakkan. antihipertensi tunggal yang tepat obat Pemilihan obat yang tepat dapat pada pasien hipertensi tanpa penyakit penyerta kardiovaskuler yaitu sebanyak $100 \%$ tepat. Tepat obat menurut Depkes RI (2015) adalah pemberian obat sesuai dengan kelas lini terapi yang sesuai dengan
Pengobatan hipertensi menjadi salah satu ukuran keberhasilan terapi pengobatan hipertensi. Menurut pedoman joint National Committee (JNC VIII) penderita hipertensi dengan diabetes mellitus dan CKD disarankan untuk memulai terapi farmakologi untuk menurunkan tekanan darah pada tekanan darah sistolik atau tekanan darah diastolik, dan memberikan terapi hingga target tekanan darah mencapai. Untuk kombinasi obat antihipertensi sebaiknya dipilihkan dari golongan yang berbeda, dimulai dari dosis yang lebih rendah untuk meningkatkan keefektifan dan mengurangi insidens terjadinya efek samping. dipertimbangkan dari ketepatan kelas lini terapi dan jenis obat yang sesuai dan terbukti manfaat dan keamanannya. Evaluasi ketepatan pemilihan obat hipertensi merupakan salah satu proses penilaian pemilihan 
obat yang sesuai dengan yang dibutuhkan pasien disesuaikan dengan jumlah kunjungan pasien dan pola penyakitnya, formularium, serta Buku Standar diagnose dan terapi (Kusumadewi, 2011).

Terapi obat dalam penelitian ini adalah ketepatan pemilihan obat antihipertensi pada pasien hipertensi tanpa penyakit penyerta kardiovaskuler yang memiliki efek terapi yang sesuai dengan standar terapi joint National Committee (JNC VIII) 2014 dan american Heart Association(AHA) 2017. Berdasakan data yang diperoleh dari 90 kasus yang diteliti didapatkan hasil ketepatan obat sebesar 94,44\% dan ketidaktepatan obat sebesar 5,56\%. Obat golongan CCB digunakan pada pasien yang tekanan darahnya tidak terkontrol baik dengan ACEI atau $\mathrm{ARB}$, karena $\mathrm{CCB}$ dihidropiridin mempunyai kemampuan yang baik dalam waktu yang singkat. CCB golongan dihidropiridin termasuk amlodipin memiliki kemampuan memperbaiki efek vasokontriksi vasa eferen arteri ginjal, hiperplansia, dan hipertropi pembuluh darah akibat induksis angiotensin II (dispogen dan hormone oligopeptida di dalam serum darah yang menyebabkan pembuluh darah mengkerut hingga menyebabkan kenaikan tekanan darah), sehingga CCB efekttif untuk proteksi terhadap ginjal, jantung dan penyakit pembuluh darah (Kabo, 2011).

Berdasarkan obat antihipertensi kombinasi yang tepat obat untuk pasien hipertensi tanpa penyakit penyerta kardiovaskuler adalah sebanyak 89,13\%, sedangkan untuk kombinasi obat yang tidak tepat sebanyak 10,87\%. Pada penelitian ini obat kombinasi yang paling banyak adalah kombinasi antara obat golongan $\mathrm{CCB}$ dengan $\mathrm{ARB}$ untuk jenis obat amlodipin-candesartan $(43,48 \%)$.

\section{Evaluasi Ketepatan Dosis Obat Antihipertensi}

Tabel 4. Distribusi Penggunaan Dosis Obat Antihipertensi pada Pasien Hipertensi Tanpa Penyakit Penyerta kardiovaskuler Berdasarkan Drug Information Handbook (DIH) 2017.

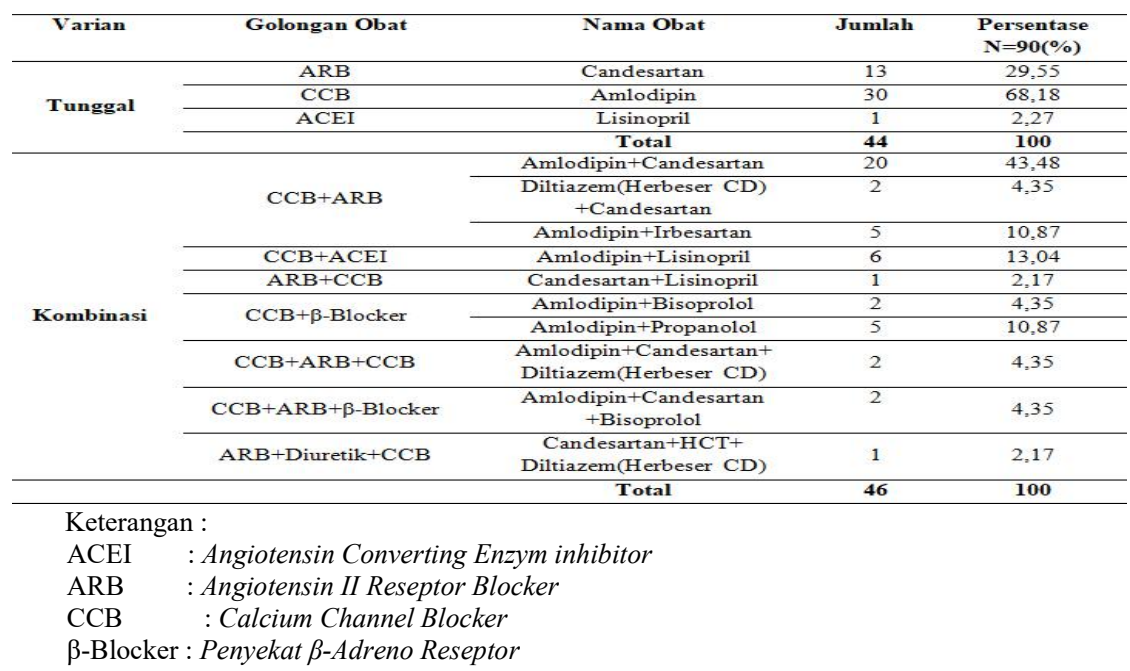

Berdasarkan tabel 4, Dosis obat antihipertensi yang tepat sebanyak 100\%. Berdasarkan Drug Information handbook (DIH) 2017 evaluasi ketepatan dosis obat harus sesuai dengan range terapi obat yang akan digunakan. Obat mempunyai karakteristik farmakokinetik maupun 
farmakodinamik yang akan mempengaruhi kadar obat dalam darah dan efek terapi obat. Dosis juga harus disesuaikan berdasarkan usia, berat badan dan status kesehatan pasien (pertimbangan fisiologis) (Rahman et al, 2014). Dosis, cara dan lama pemberian obat sangat mempengaruhi efek terapi obat. Pemberian dosis yang berlebih, khususnya obat dengan rentang terapi yang sempit, akan sangat beresiko terhadap timbulnya efaek samping, sebaiknya dosis yang terlalu kecil tidak akan menjamin tercapainya kadar terapi yang diharapkan
(Kemenkes, 2011). Tepat dosis meliputi besarnya takaran dosis dan untuk frekuensi pemberian dosis perhari. Hasil penelitian menunjukkan tepat dosis pemberian obat antihipertensi tunggal dan kombinasi sebanyak $100 \%$ tepat berdasarkan buku standar Drug Infoemation Handbook (DIH 2017). Tanpa melihat pertimbangan-pertimbangan medis, karena metode pengambilan data yang digunakan yaitu metode retrospektif (pengambilan data sekunder). Untuk frekuensi pemberian obat antihipertensi dosis perhari yang tepat $100 \%$.

Tabel 5. Distribusi Frekuensi Pemberian Dosis Obat Antihipertensi

\begin{tabular}{|c|c|c|c|c|c|}
\hline \multirow[t]{2}{*}{ Nama Obat } & \multirow{2}{*}{$\begin{array}{l}\text { Jumlah } \\
\text { Kasus }\end{array}$} & \multirow{2}{*}{$\begin{array}{c}\text { Dosis Standar } \\
\text { (mg/hari) }\end{array}$} & \multirow{2}{*}{$\begin{array}{c}\begin{array}{c}\text { Kesesuaian } \\
\text { Dosis }\end{array} \\
\begin{array}{c}\text { Tidak } \\
\text { sesuai }\end{array} \\
\end{array}$} & \multicolumn{2}{|c|}{$\begin{array}{c}\text { Persentase } \\
\text { Kesesuaian } \\
\text { Dosis }(\%)\end{array}$} \\
\hline & & & & Sesuai & $\begin{array}{l}\text { Tidak } \\
\text { sesuai }\end{array}$ \\
\hline Amlodipin & 30 & $2,5-10$ & & 33,3 & \\
\hline Candesartan & 13 & $8-32$ & - & 14,44 & - \\
\hline Lisinopril & 1 & $150-300$ & - & 1,11 & - \\
\hline Amlodipin+Candesartan & 20 & $2,5-10 / 8-32$ & - & 22,22 & - \\
\hline $\begin{array}{c}\text { Diltiazem(Herbeser CD) } \\
\text { +Candesartan }\end{array}$ & 2 & $180-240 / 8-32$ & - & 2,22 & - \\
\hline Amlodipin+Irbesartan & 5 & $2,5-10 / 150-300$ & - & 5,56 & - \\
\hline Amlodipin+Lisinopril & 6 & $2,5-10 / 5-10$ & - & 6,67 & - \\
\hline Candesartan+Lisinopril & 1 & $8-32 / 5-10$ & - & 1,11 & - \\
\hline Amlodipin+Bisoprolo1 & 2 & $2,5-10 / 2,5-5$ & - & 2,22 & - \\
\hline Amlodipin+Propanolol & 5 & $2,5-10 / 40-160$ & - & 5,56 & - \\
\hline $\begin{array}{l}\text { Amlodipin+Candesartan+ }+ \\
\text { Diltiazem(Herbeser CD) }\end{array}$ & 2 & $\begin{array}{l}2,5-10 / 8-32 \\
1180-240\end{array}$ & - & 2,22 & - \\
\hline $\begin{array}{c}\text { Amlodipin+Candesartan } \\
+ \text { Bisoprolol }\end{array}$ & 2 & $\begin{array}{c}2,5-10 / 8-32 / \\
2,5-5\end{array}$ & - & 2,22 & - \\
\hline $\begin{array}{c}\text { Candesartan+HCT+ } \\
\text { Diltiazem (Herbeser CD) }\end{array}$ & 1 & $\begin{array}{c}8-32 / 12,5-50 \\
180-240\end{array}$ & - & 1,11 & - \\
\hline Total & 90 & 90 & $\mathbf{0}$ & 100 & $\mathbf{0}$ \\
\hline
\end{tabular}

Berdasarkan tabel 5 frekuensi pemberian dosis yang sesuai $100 \%$ dari jumlah keseluruhan 90 pasien yang diambil datanya.

\section{Analisis Univariat}

\section{Obat Antihipertensi}

Tabel 6. Distribusi Frekuensi Berdasarkan Ketepatan Obat Antihipertensi yang Digunakan pada Pasien Hipertensi Tanpa Penyakit Penyerta Kardiovaskuler

\begin{tabular}{ccc}
\hline Obat & Jumlah Pasien & Persentase $\%(\mathbf{N}=\mathbf{3 1})$ \\
\hline Tepat & 85 & 94,44 \\
\hline Tidak tepat & 5 & 5,56 \\
\hline Total & $\mathbf{9 0}$ & $\mathbf{1 0 0}$
\end{tabular}

kardiovaskuler di Rumah Sakit Bhakti

Berdasarkan tabel 6, dapat dilihat bahwa ketepatan pemilihan obat antihipertensi pada pasien hipertensi tanpa penyakit penyerta
Wira Tamtama Semarang tahun 2019 sebesar 94,44\%, sedangkan kasus terapi antihipertensi yang tidak tepat sebesar 5,56\%. 
2. Dosis Obat antihipertensi

Tabel 7. Distribusi Frekuensi Ketepatan Penggunaan Dosis Antihipertensi yang Digunakan pada Pasien Hipertensi Tanpa Penyakit Penyerta Kardiovaskuler

\begin{tabular}{ccc}
\hline Dosis & Jumlah & Persentase \% \\
\hline Tepat & 90 & 100 \\
\hline Tidak Tepat & 0 & 0 \\
\hline Total & $\mathbf{9 0}$ & $\mathbf{1 0 0}$
\end{tabular}

Berdasarkan Tabel 7, dapat diketahui bahwa besaran dosis antihipertensi yang digunakan secara tepat adalah $100 \%$.

Tabel 8. Distribusi Frekuensi Berdasarkan Tekanan Darah pada Pasien Hipertensi Tanpa penyakit penyerta Kardiovaskuler

\begin{tabular}{ccc}
\hline Tekanan Darah & Jumlah & Persentase \% \\
\hline Terkontrol & 32 & 42,22 \\
\hline Tidak Terkontrol & 52 & 57,78 \\
\hline Total & $\mathbf{9 0}$ & $\mathbf{1 0 0}$
\end{tabular}

\section{Berdasarkan tabel 8, Ketepatan SARAN}

obat dan dosis obat terhadap keberhasilan terapi pada pasien hipertensi tanpa penyakit penyerta kardiovaskuler adalah pasien yang tidak terkontrolnya tekanan darahnya sebanyak 38 pasien yaitu $42,22 \%$ dan pasien yang terkontrol tekanan darahnya sebanyak 52 pasien yaitu $57,78 \%$. Pengobatan hipertensi seharusnya dilakukan secara berkelanjutan dan dalam jangka waktu yang panjang hingga tekanan darah dapat terkontrol. Walaupun keluhan sudah hilang, pasien hipertensi tetap harus mengkonsumsi obat hingga tekanan darahnya benar - benar terkontrol. Hal ini diakibatkan karena hipertensi sering tidak menimbulkan gejala dan keluhan yang khas, sehingga sulit disadari oleh penderita (Mathavan dan Pinatih, 2017).

\section{SIMPULAN}

Obat antihipertensi yang tepat adalah 85 pasien $(94,44 \%)$, sedangkan yang tidak tepat 5 pasien $(5,56 \%)$ dari 90 pasien. Pemberian dosis pada 90 pasien mengalami ketepatan sebanyak (100\%) yang didalamnya termasuk dalam frekuensi pemberian yang sesuai. Dosis terapi sesuai dengan DIH (Drug Information Handbook) tahun 2017.

Perlu dilakukan penelitian prospektif lebih lanjut mengenai ketepatan obat dan dosis obat antihipertensi terhadap keberhasilan terapi pasien hipertensi sehingga dapat dilihat efek yang akan terjadi dan kepatuhan pasien minum obat.

\section{DAFTAR PUSTAKA}

American Heart Association (AHA). 2017. Cardiovascular Disease : A Costly Burden For America Projections Through 2035. The American Heart Association Office of Federal Advocacy : Washington DC;2017.

Depkes RI, 2013. Riset Kesehatan Dasar. Jakarta: Badan Penelitian dan pengembangan Kesehatan Kementrian Kesehatan RI.

Depkes RI. 2015. Profil Kesehatan Provinsi Jawa Tengah.

Drug Information Handbook. 2017. Edisi $26^{\text {th }}$

James, P.A., Oparil, S., Carter, B.L, Cushman, W.C., DennisonHimelfarb, C., Handler et al., 2014. Evidence-Based Guideline for The Management of High Blood Pressure in Adults Report from The Panel Members Appointed to The Eighth Joint National 
Committee (JNC 8). JAMA. 311(5), 507-520.

JNC 8 Hypertension Guideline: An InDepth Guide [published online January 21, 2014]. The American Journal of Managed Care. 2014.

Kabo, P., 2011, Bagaimana Menggunakan Obat-obat Kardiovaskuler Secara Rasional, Halaman 63-98. Jakarta, Balai Penerbit FKUI.

Kementerian kesehatan RI, 2011. Tentang Standar Pelayanan Keperawatan Gawat Darurat di Rumah Sakit. Jakarta: Menteri Kesehatan Republik Indonesia.

Kementerian Kesehatan RI, 2015. Rencana Strategis Kementerian Kesehatan Tahun 2015-2019. Jakarta: Kementerian Kesehatan RI.

Kemenkes RI, 2013. Riset Kesehatan Dasar : Riskesdas 2013, 177-132, Kementrian Kesehatan Republik Indonesia, Jakarta.

Kusumadewi S. W., 2011. Uji Efek Senyawa Eugenol terhadap Kultur Sel Kanker Servuks (Hella Cell Line). Skripsi. Fakultas Kedokteran UIN Jakarta.

Mathavan J, Pinantih GNI. 2017. Gambaran Tingkat Pengetahuan Terhadap Hipertensi dan Kepatuhan Berobat pada Pasien Hipertensi di Puskesmas Ranotana Weru. e-journal Keperawatan (e$K p)$. Universitas Sam Ratulangi.

Notoatmodjo, S., 2012. Pengolahandan Analisa Data. Dalam: Notoatmodjo, S., Edisi revisi cetakan kedua. Metodologi Penelitian Kesehatan. Jakarta.

Rahman ZU, Irshad M, Khan I, Baig Alija, and Khan FA. 2014. Calculating Drug Dosage, Creatinine Clearance and Enteral-Parenteral Nutrition. The Pharma
Innovation-Jourlan, Vol. 3. No. 1:11-17.

World Health Organization. 2013. A global brief on Hypertension :Silent Kliller, global public healthcrisis, 9, 20, World Health Organization Press, Gene 